\title{
Screening of Kunun-zaki for Methicillin-Resistant Staphylococcus aureus (MRSA), Vancomycin-Resistant Staphylococcus aureus (VRSA) and Extended-Spectrum Beta-Lactamase (ESBL) Producing Salmonella
} spp.

\author{
Edward Kelechi ${ }^{1}$, Daniel Emeaso ${ }^{1}$, Alozie Chukwuemeka ${ }^{1,2}$, Owuamalam Precious ${ }^{1,3}$, \\ Onyekachi Onyedikachi ${ }^{1,4}$
}

${ }^{1}$ Michael Okpara University of Agriculture, Umudike

PMB 7267, Umuahia, Abia State, Nigeria

2 University of Bath

BA2 7AY, Claverton Down, Bath, United Kingdom

${ }^{3}$ University of Birmingham

B15 2TT, Edgbaston, Birmingham, United Kingdom

${ }^{4}$ University of Leicester

LE1 7RH, University Road, Leicester, United Kingdom

DOI: $10.22178 /$ pos.64-7

LCC Subject Category:

QH301-705.5

Received 16.09.2020

Accepted 28.11.2020

Published online 30.11 .2020

Corresponding Author:

Edward Kelechi

Edward.kelechi@mouau.edu.ng

(C) 2020 The Authors. This article

is licensed under a Creative

Commons Attribution 4.0

License @ (1)
Abstract. Kunun-zaki is an indigenous, fermented, non-alcoholic cereal-based beverage produced and consumed primarily in Northern Nigeria. Due to its high nutritional and moisture content, it provides an ideal environment for the growth of foodborne pathogens. This study determined the presence of Methicillin resistant Staphylococcus aureus (MRSA), vancomycin resistant Staphylococcus aureus (VRSA) and Extended spectrum beta lactamase (ESBL) producing Salmonella spp in Kunun-zaki sold in Umuahia metropolis, Nigeria. Out of the 40 Kunun-zaki samples examined, Salmonella spp was detected in 19 (47.5\%), whereas S. aureus was detected in $22(55 \%)$ of the samples. The total Salmonella count ranged from $1.90 \times 10^{5}-9.70 \times 10^{6}(\mathrm{CFU} / \mathrm{ml})$, whereas the total $S$. aureus count ranged from $3.40 \times 10^{4}-7.50 \times 10^{6}(\mathrm{CFU} / \mathrm{ml})$; these microbial counts do not conform to the standard limits of detectable microbes in ready-to-eat food samples as stipulated by the Center for Food Safety. All the isolates were subjected to antibiotic susceptibility testing using the modified Kirby Bauer disc diffusion method. On the one hand, most of the Salmonella spp were resistant to the betalactam class of antibiotics used (IMP 58\%, MEM 90\%, AMP 53\%). On the other hand, the Salmonella isolates showed the highest sensitivities to ceftazidime $(95 \%)$ and ofloxacin (90\%). The S. aureus isolates revealed high susceptibility to ofloxacin (96\%), and major resistance to oxacillin (41\%) and the oxyiminocephalosporin antibiotics used (CAZ 55\%, CTR 41\%). MRSA, VRSA and ESBL producing Enterobacteriaceae are amongst the most critical multidrug-resistant bacterial pathogens. In this study, $26 \%$ of the Salmonella spp isolates were confirmed to be ESBL producers, whereas $41 \%$ of the isolates were MRSA, $23 \%$ were VRSA, and $68 \%$ were Vancomycin intermediate Staphylococcus aureus (VISA). Hence, the Kunun-zaki could constitute a reservoir for the dissemination of multidrug-resistant foodborne pathogens if not correctly quality controlled.

Keywords: Kunun-zaki; Staphylococcus aureus; Salmonella spp; Extended spectrum beta-lactamase (ESBL); Methicillin-resistant Staphylococcus aureus (MRSA); Vancomycin-resistant Staphylococcus aureus (VRSA); Multidrug resistance (MDR). 


\section{INTRODUCTION}

Kunun-zaki is a fermented, non-alcoholic, noncarbonated and refreshing cereal-based beverage widely consumed in Nigeria, particularly in Northern Nigeria [1]. Kunun-zaki gets its appeal from the distinctive sweet-and-sour taste characteristic of African food products fermented by Lactic Acid Bacteria (LAB) [2], as well as its purported medicinal, nutritional, and thirst-quenching properties $[3,4,5]$.

Traditionally, the production procedure of Kunun-zaki varies depending on the taste and culture of the producers and consumers, thus leading to variation in the quality and stability of the Kunun-zaki. Generally, Kunun-zaki is produced from the following cereal substrates; millet, maize, wheat, rice, acha (Digitaria exilis) and sorghum, but millet is mostly used for commercial production $[3,6]$. It is usually flavoured with a combination of spices such as ginger, cloves, black pepper, cinnamon, red pepper and sweeteners such as sugar and honey, together with small quantities of saccharifying agents such as paste of sweet potato tubers, malted rice and malted sorghum [6]. Kunun-zaki is relatively cheap to purchase because the ingredients and cereals used in its production are locally sourced as they are grown throughout the savannah belt of West Africa [7].

The preparation method for Kunun-zaki involves cleaning the grains of the cereals and steeping them in water for 1-3 days. This is then followed by grinding the steeped grains into a mash. The mash of cereals is then divided into two portions in a ratio of about 1:2, the larger portion is gelatinized with hot water whilst, the smaller portion is mixed with spices and the saccharifying agent. These ingredients are usually not quantified [8]. The two parts are then combined at $70-75^{\circ} \mathrm{C}$, and the mixture is left to ferment at room temperature for 18-24 hours. The product is filtered, and sweeteners are added to the filtrate to taste, and the Kunun-zaki is now ready for consumption [3, 9]. The drink is usually packaged and sold in $500 \mathrm{ml}$ plastic bottles (obtained from used water or carbonated drinks) and at times, even tied in some disposable polyethene bags [10].

Kunun-zaki has a concise shelf life of about 24 hours [2], readily undergoing microbial spoilage due to poor keeping conditions. Attempts to improve the shelf-life have been met with some success; pasteurization of packaging bottles followed by refrigeration storage of the Kunun-zaki prolonged the shelf life to 8 days [11], whilst using sodium benzoate (a known preservative) followed by refrigeration extended the shelf to 21 days [12].

Studies have shown that Kunun-zaki has an essential role in the dietary pattern of its consumers owing to its richness in carbohydrates, vitamins, minerals, and moisture content. However, it is low in total protein content $[4,5]$. The health benefits of Kunun-zaki includes but is not limited to: reduction of risk associated with diabetes, lowering of blood cholesterol, prevention of blood clotting [13], and increased lactation in nursing mothers [14].

Considering that Kunun-zaki is a nutritionally enriched food product with a very high moisture content and lacks standardization and quality control in both sourcing of cereals, processing, storage, handling, packaging, and delivery to customers, Kunun-zaki provides an ideal environment for the growth of foodborne microbial pathogens which include members of the Enterobacteriaceae, Staphylococcus aureus, and Bacillus cereus, among others, hence, predisposing consumers to serious health risks $[15,16]$.

S. aureus is a normal flora of the human skin, throat, nasal passage, fingernails, and hair. However, $S$. aureus is implicated in several infections, including meningitis, septicemia, pneumonia, endocarditis and osteomyelitis [17]. When ingested with food, $S$. aureus can cause food poisoning due to its ability to produce several enterotoxins. Also, $S$. aureus may even cause scalded skin syndrome and toxic shock syndrome through the production of different toxins [18]. S. aureus, in general, is sensitive to many antibiotics; however, in the last few decades, many strains of $S$. aureus have developed resistance to these antibiotics. S. aureus resistance to methicillin is of severe public health concern due to its high morbidity and mortality [19]. Methicillin-resistant Staphylococcus aureus (MRSA) occurs as a result of the acquisition of Staphylococcal Cassette Chromosome mec (SCC$m e c$ ) genes by methicillin-sensitive $S$. aureus. The SCCmec is a mobile genetic element which carries the mecA or mec $\mathrm{C}$ gene which encodes the penicillin-binding protein (PBP2a) that confers resistance to all beta-lactam antibiotics [20-22]. The SCCmec also contains site-specific recombinase genes (cassette chromosome recombinase ( $\mathrm{ccr}$ )) $c c r \mathrm{AB}$ or/and $c c r \mathrm{C}$ which mediates integration and excision of SCCmec into or from the chromosome. In addition, the SCCmec contains a few other genes and various other mobile genetic 
elements such as insertion sequences, transposons, and plasmids [23, 24]. With the emergence of MRSA, vancomycin has been utilized as the treatment of choice for MRSA infections, and its excessive use has led to the emergence of Vancomycin Intermediate and Vancomycin-Resistant $S$. aureus (VISA and VRSA) [25].

Contamination of food by Enterobacteriaceae is usually through faecal water contamination, and cross-contamination may occur during further processing and preparation. The Enterobacteriaceae consists of some essential public health pathogens that produce extended-spectrum betalactamases (ESBL), which are a group of enzymes conferring broad resistance to beta-lactams: oxyimino-cephalosporins (such as cefotaxime, ceftriaxone, ceftazidime or cefepime) and monobactams (aztreonam) but not carbapenems [26, 27]. The enzyme generally results from a point mutation in the genes of broad-spectrum beta-lactamases, TEM-1 and SHV-1, by one to four amino acid changes which form the bases of resistance [28]. ESBL enzymes are usually located on plasmids that often carry other resistance genes that confer reduced susceptibility to other unrelated classes of antimicrobials making it difficult to treat infections caused by ESBL producing bacteria $[29,30]$, and resistance can be easily transmitted among members of the Enterobacteriaceae through plasmid-mediated transfer. An essential member of the Enterobacteriaceae is Salmonella spp, which typically resides in the intestinal tract of animals and humans and are shed through faeces.

In developing countries like Nigeria, control over the processing and sales of hawked foods have not been achieved presumably because most of the vendors and sellers lack adequate knowledge of food processing and handling practices. As a result, extensive studies have been conducted on the nutritional and microbial quality of Kunun-zaki and other hawked indigenous drinks and beverages to increase public awareness, and draw the attention of the relevant food authorities to the health risks and hazards associated with the consumption of such contaminated food products $[15,31-34]$. Following up from our previous study [15], in this study, we aimed to determine the presence of methicillin-resistant Staphylococcus aureus (MRSA), vancomycin-resistant Staphylococcus aureus (VRSA) and extended-spectrum beta-lactamase (ESBL) producing Salmonella spp in Kunun-zaki drinks sold in Umuahia metropolis, Nigeria.

\section{MATERIALS AND METHODS}

\section{Sample collection}

Forty (40) samples of Kunun-zaki were purchased randomly from different hawkers within Umuahia metropolis, Nigeria. The samples were transported to the laboratory in an icebox within an hour of collection and were preserved in a refrigerator at $4{ }^{\circ} \mathrm{C}$ before being analyzed. The samples were analyzed within two hours of collection.

\section{Media used}

All the media used for this study were obtained from Titan Biotech Ltd. Rajasthan, India. The media were prepared according to the manufacturers' instructions.

\section{Salmonella spp identification and characterization}

An aliquot of each sample (1 $\mathrm{ml})$ was enriched in a $1: 10$ ratio of peptone water at $37^{\circ} \mathrm{C}$ for 24 hours. The enriched samples were serially diluted up to $10^{5}$ and $0.1 \mathrm{ml}$ of the appropriate dilutions were spread plated on Salmonella Shigella Agar (SSA) and incubated at $37^{\circ} \mathrm{C}$ for 24 hours. Presumptive distinct colonies (SSA: black-centred colonies) were counted and expressed as Salmonella spp colony forming unit per millilitre $(\mathrm{CFU} / \mathrm{ml})$ of each Kunun-zaki sample. Single colonies of Salmonella spp were sub-cultured for 24 hours at $37^{\circ} \mathrm{C}$ on nutrient agar to obtain pure cultures for biochemical identification and antimicrobial testing. Presumptive colonies were tested for the biochemical properties of Salmonella spp (oxidase reaction, citrate utilization test, indole production test, urease test, triple sugar iron test and $\mathrm{H}_{2} \mathrm{~S}$ production).

\section{Staphylococcus aureus identification and characteri- zation}

An aliquot of each sample ( $1 \mathrm{ml}$ ) was enriched in a $1: 10$ ratio of peptone water at $37^{\circ} \mathrm{C}$ for 24 hours. The enriched samples were serially diluted up to $10^{5}$ and $0.1 \mathrm{ml}$ of the appropriate dilutions were spread plated on Mannitol-salt Agar (MSA) and incubated at $37^{\circ} \mathrm{C}$ for 24 hours. Presumptive distinct colonies (MSA: yellow colonies with yellow zones) were counted and expressed as $S$. aureus colony forming unit per millilitre $(\mathrm{CFU} / \mathrm{ml})$ of each Kunun-zaki sample. Single colonies of $S$. aureus were sub-cultured for 24 hours at $37^{\circ} \mathrm{C}$ on 
nutrient agar to obtain pure cultures for biochemical identification and antimicrobial testing. Presumptive colonies were tested for the biochemical properties of $S$. aureus (catalase reaction, coagulase test, citrate utilization test, oxidase reaction, urease, and indole production test).

\section{Salmonella spp antibiotic resistance profiles}

To assess the antibiotic resistance profiles of the Salmonella isolates, standard inoculums of the isolates were prepared from the pure cultures of Salmonella spp as described by Cheesbrough [35]. Standardized inoculums (one loopful) of each of the samples were subjected to susceptibility testing on Mueller Hinton Agar against 12 antimicrobial agents according to the Clinical and Laboratory Standards Institute (CLSI) protocol and criteria [36]. The following antibiotics were used: ceftazidime (CAZ; 30 $\mu \mathrm{g}$ ), cefuroxime (CRX; $30 \mu \mathrm{g}$ ), gentamicin (GEN; $10 \mu \mathrm{g}$ ), ciprofloxacin (CPR; 5 $\mu \mathrm{g}$ ), ofloxacin (OFL; $5 \mu \mathrm{g}$ ), augmentin (AUG; 30 $\mu \mathrm{g}$ ), nitrofurantoin (NIT; $300 \mu \mathrm{g}$ ), ampicillin (AMP; $10 \mu \mathrm{g}$ ), aztreonam (ATM; $30 \mu \mathrm{g}$ ), ceftriaxone (CTR; $30 \mu \mathrm{g}$ ), imipenem (IMP; $10 \mu \mathrm{g}$ ) and meropenem (MEM; $10 \mu \mathrm{g}$ ) (Rapid labs. Ltd. Colchester, Essex, United Kingdom).

\section{Staphylococcus aureus antibiotic resistance profiles: Methicillin-resistant Staphylococcus aureus and Vancomycin-resistant Staphylococcus aureus}

To assess the antibiotic resistance profiles of the $S$. aureus isolates, standard inoculums of the isolates were prepared from the pure cultures of $S$. aureus as described by Cheesbrough [35]. Standardized inoculums (one loopful) of each of the samples were subjected to susceptibility testing on Mueller Hinton Agar against ten antimicrobial agents according to the Clinical and Laboratory Standards Institute (CLSI) protocol and criteria [36]. The following antibiotics were used: ceftazidime (CAZ; $30 \mu \mathrm{g}$ ), ceftriaxone (CTR; $30 \mu \mathrm{g}$ ), gentamicin (GEN; $10 \mu \mathrm{g}$ ), ciprofloxacin (CPR; $5 \mu \mathrm{g}$ ), ofloxacin (OFL; $5 \mu \mathrm{g}$ ), augmentin (AUG; $30 \mu \mathrm{g}$ ), erythromycin (ERY; $5 \mu \mathrm{g}$ ), vancomycin (VAN; $10 \mu \mathrm{g}$ ), oxacillin (OXA; $5 \mu \mathrm{g}$ ) and cloxacillin (CXC; $5 \mu \mathrm{g}$ ) (Rapid labs. Ltd. Colchester, Essex, United Kingdom).

\section{Detection of Extended spectrum beta-lactamases (ESBL) producing Salmonella spp}

For detection of ESBL producing Salmonella spp, isolates with zones of inhibition (in diameters) of $<25 \mathrm{~mm},<22 \mathrm{~mm}$ and $<27 \mathrm{~mm}$ for ceftriaxone (CTR; $30 \mu \mathrm{g}$ ), ceftazidime (CAZ; $30 \mu \mathrm{g}$ ) and aztreonam (ATM; $30 \mu \mathrm{g}$ ) respectively from the antibiotic resistance profiling were regarded as potential ESBL producers according to the Clinical and Laboratory Standards Institute (CLSI) criteria [37], and subjected to a confirmatory Double Disc Synergy Test (DDST). The DDST confirmatory test was carried out as described by Jarlier et al. [38] using two oxyimino-cephalosporins (CTR and CAZ) and a monobactam (ATM) all placed at 20 $\mathrm{mm}$ distance apart center to center from an AUG disc placed at the center. Positive DDST result is indicated by an enhancement of inhibition zone of the cephalosporins and monobactam towards the central augmentin disc $[39,40]$.

\section{RESULTS AND DISCUSSION}

\section{Presence of Foodborne Pathogens}

To assess the presence of selected bacterial foodborne pathogens, forty (40) hawked Kunun-zaki samples were examined for Salmonella spp and $S$. aureus.

Salmonella spp were detected in 19 (47.5\%) out of the 40 Kunun-zaki samples examined (Figure 1), and the total Salmonella spp count $(\mathrm{CFU} / \mathrm{ml})$ ranged from $1.90 \times 10^{5}-9.70 \times 10^{6}$ (Table 1).

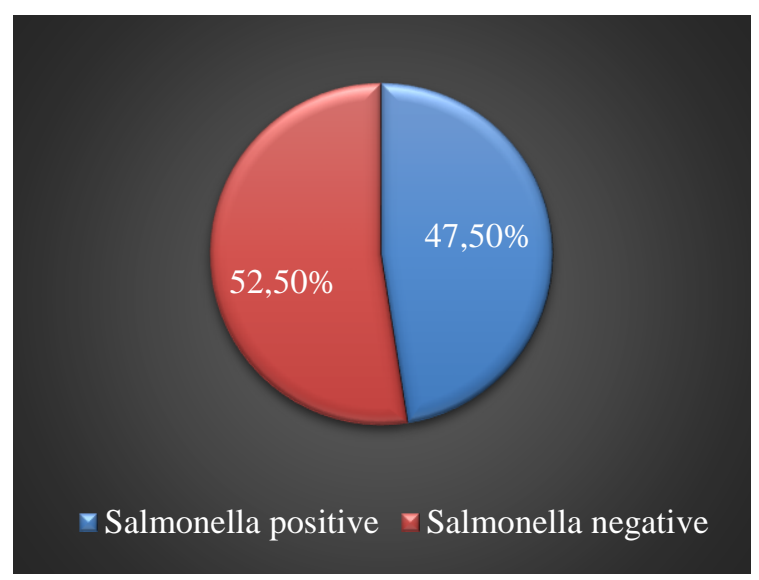

Figure 1 - Percentage occurrence of Salmonella spp isolates from the Kunun-zaki 
Table 1 - The Salmonella spp count (CFU/ml) and $S$. aureus count (CFU/ml) in the Kunun-zaki samples

\begin{tabular}{|c|c|c|}
\hline $\begin{array}{c}\text { Kunun-zaki } \\
\text { samples }\end{array}$ & $\begin{array}{c}\text { Salmonella spp } \\
\text { count (CFU/ml) }\end{array}$ & $\begin{array}{c}\text { S. aureus count } \\
\text { (CFU/ml) }\end{array}$ \\
\hline KZ1 & $1.27 \times 10^{6}$ & $3.40 \times 10^{5}$ \\
\hline KZ2 & - & $4.50 \times 10^{5}$ \\
\hline KZ3 & - & $5.90 \times 10^{5}$ \\
\hline KZ4 & $8.30 \times 10^{6}$ & $3.70 \times 10^{5}$ \\
\hline KZ7 & $7.70 \times 10^{5}$ & $5.60 \times 10^{5}$ \\
\hline KZ8 & $8.00 \times 10^{5}$ & - \\
\hline KZ9 & $6.70 \times 10^{5}$ & - \\
\hline KZ10 & - & $6.40 \times 10^{5}$ \\
\hline KZ11 & - & $3.60 \times 10^{5}$ \\
\hline KZ12 & - & $5.90 \times 10^{6}$ \\
\hline KZ13 & $5.50 \times 10^{5}$ & $1.58 \times 10^{6}$ \\
\hline KZ14 & - & $6.40 \times 10^{6}$ \\
\hline KZ16 & $7.60 \times 10^{5}$ & - \\
\hline KZ18 & $1.90 \times 10^{5}$ & - \\
\hline KZ19 & $3.60 \times 10^{6}$ & $6.90 \times 10^{5}$ \\
\hline KZ20 & $7.40 \times 10^{5}$ & - \\
\hline KZ21 & $3.40 \times 10^{5}$ & $1.37 \times 10^{6}$ \\
\hline KZ22 & - & $7.50 \times 10^{5}$ \\
\hline KZ24 & $3.20 \times 10^{5}$ & - \\
\hline KZ25 & - & $6.80 \times 10^{5}$ \\
\hline KZ27 & $6.30 \times 10^{5}$ & - \\
\hline KZ28 & - & $7.40 \times 10^{5}$ \\
\hline KZ29 & - & $3.40 \times 10^{4}$ \\
\hline KZ30 & $9.10 \times 10^{5}$ & $6.50 \times 10^{5}$ \\
\hline KZ31 & - & $1.28 \times 10^{6}$ \\
\hline KZ33 & $1.12 \times 10^{6}$ & - \\
\hline KZ34 & $7.30 \times 10^{5}$ & $7.80 \times 10^{5}$ \\
\hline KZ35 & $7.40 \times 10^{5}$ & $1.46 \times 10^{6}$ \\
\hline KZ36 & - & $5.70 \times 10^{5}$ \\
\hline KZ38 & $1.78 \times 10^{6}$ & - \\
\hline KZ39 & $9.70 \times 10^{6}$ & - \\
\hline KZ40 & - & $7.50 \times 10^{6}$ \\
\hline & & \\
\hline
\end{tabular}

Notes: KZ= Kunun-zaki sample

Previous reports have shown varying percentage rates of incidence. For instance, Gyar et al. [41] reported the recovery of Salmonella in 7 (28\%) out of 25 Kunun-zaki samples examined in Keffi Metropolis, Nigeria; whilst Braide et al. [42] reported the recovery of Salmonella from 12 (75\%) out of 16 Kunun-zaki samples bought and examined in Owerri, Nigeria. More so, Aboh and Oladosu [43] reported the recovery of Salmonella from 1 (2.4\%) out of a total of 41 Kunun-zaki samples examined in Abuja, Northern Nigeria. The disparity in the number of Salmonella isolates may be due to the differences in the number of Kunun-zaki samples studied, the isolation procedures implemented and the cultural habit of the population; as well as discrepancies in the quality control standards in the processing, preparation, storage, packaging and delivery of the Kunun-zaki.

According to the Center for Food Safety [44], there should be no detectable Salmonella spp in any $\mathrm{mg} / \mathrm{ml}$ of any processed food substance ready and fit for human consumption. Salmonella spp are a significant cause of foodborne diseases and may colonize the intestinal tract of a large number of mammals and birds causing symptoms such as nausea, vomiting, abdominal cramps, diarrhoea fever, and headache [45].

Going forward, S. aureus was detected in 22 (55\%) out of the 40 Kunun-Zaki samples (Figure 2), and the total $S$. aureus count $(\mathrm{CFU} / \mathrm{ml})$ ranged from $3.40 \times 10^{4}-7.50 \times 10^{6}$ (Table 1 ).

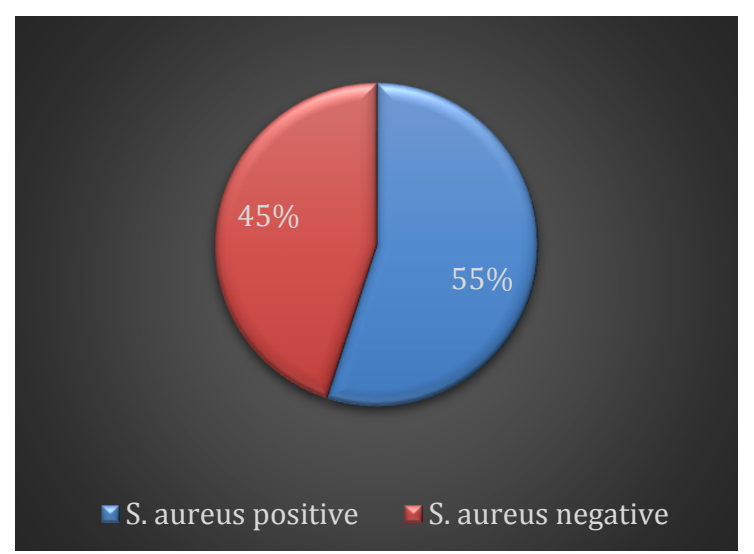

Figure 2 - Percentage occurrence of $S$. aureus isolates from the Kunun-zaki samples

Similar results have been reported in previous studies, although with a higher percentage rate of incidence. For instance, Gyar et al. [41] reported that $18(72 \%)$ out of the total 25 Kunun-zaki samples examined in Keffi metropolis, Nigeria, were contaminated with $S$. aureus, whilst Braide et al. [42] reported the recovery of $S$. aureus from 11 (69\%) out of the 16 Kunun-zaki samples examined in Owerri, Nigeria. Aboh and Oladosu [43] reported a much lower incidence rate in Abuja, Nigeria (6 (14.6\%) S. aureus positive samples out of the total 41 Kunun-zaki samples examined).

Again, the discrepancies in the number of $S$. aureus isolates reported might be attributed to the differences in the number of Kunun-zaki samples examined, the isolation procedures implemented and probably, the cultural habit of the population; as well as the discrepancies in the quality control standards in the processing, preparation, storage, packaging and delivery of the Kunun-zaki. 
According to the Center for Food Safety [44], the satisfactory limit for $S$. aureus detection in food is $<20 \mathrm{CFU} / \mathrm{ml}$ with a borderline of $20-\leq 10^{4}$ $\mathrm{CFU} / \mathrm{ml}$, above which the food is deemed unsatisfactory. Hence, the $S$. aureus count revealed that the Kunun-zaki drinks were unfit for consumption. S. aureus, as a foodborne pathogen has the potential to cause food poisoning or intoxication through the production of several enterotoxins.

The presence of Salmonella spp and S. aureus in Kunun-zaki samples might result from both direct contamination from the food handlers at the various stages of the unit operations; and indirectly from the water and containers used in its preparation and packaging, the substrates and ingredients used for preparation, and the environment where the Kunun-zaki samples are processed and hawked [46].

Furthermore, since the preparation process of Kunun-zaki involves pasteurization, a process that could eliminate both Salmonella spp and S. aureus, the other media through which the drinks can be contaminated would be the sugars, sweeteners and / or water added to the drink after cooling, just before packaging.

\section{Antibiotic Resistance}

Modified Kirby Bauer disc diffusion test of the isolates revealed varying levels and patterns of susceptibility to the antibiotics tested (Figure 3 and Figure 4). The Salmonella spp were resistant to the beta lactam class of antibiotics used (IMP 58\%, MEM 90\%, AMP 53\%) (Figure 3).

The $S$. aureus isolates revealed high resistance to oxacillin (41\%) and the oxyimino-cephalosporin antibiotics used (CAZ 55\%, CTR 41\%) (Figure 4). Interestingly, 91\% of the Staphylococcus aureus isolates were classified as multidrug resistant because they were MRSA and / or non-susceptible to at least one antimicrobial agent in three or more antimicrobial categories as defined by [47] (Table 2).

The persistent and indiscriminate exposure of bacterial strains to a multitude of antibiotics has led to the development of multidrug resistant bacteria [48]. Another possible medium for the development of MDR is through plasmid mediated resistance [49]. However, over $90 \%$ of the foodborne pathogens isolated from this study were susceptible to treatment with ofloxacin. This increased sensitivity to ofloxacin may stem from the fact that the antibiotics are not frequently used in therapeutic or prophylaxis therapy due to its high cost [49].

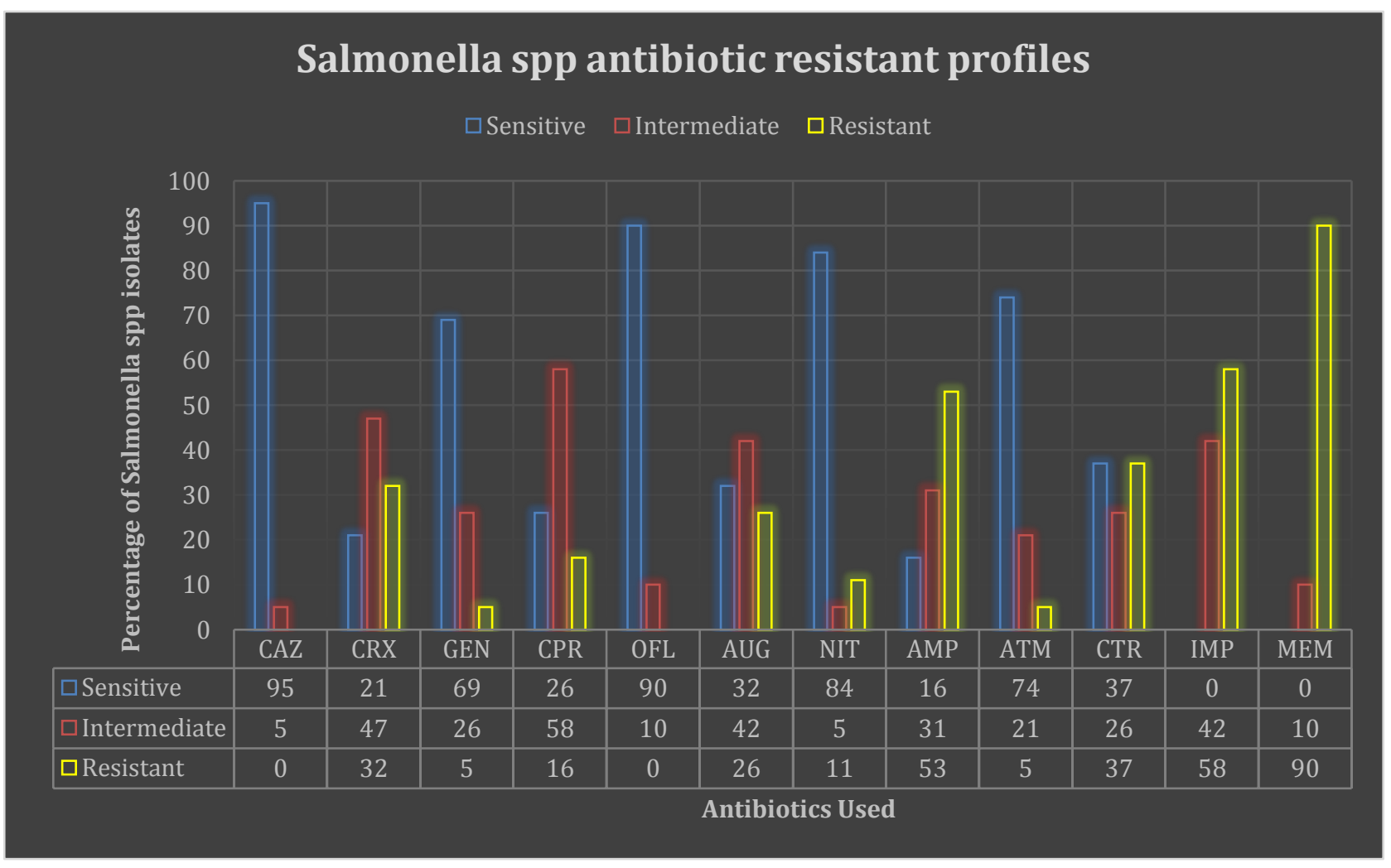

Figure 3 - Antibiotic-resistant profiles of the Salmonella spp isolates 


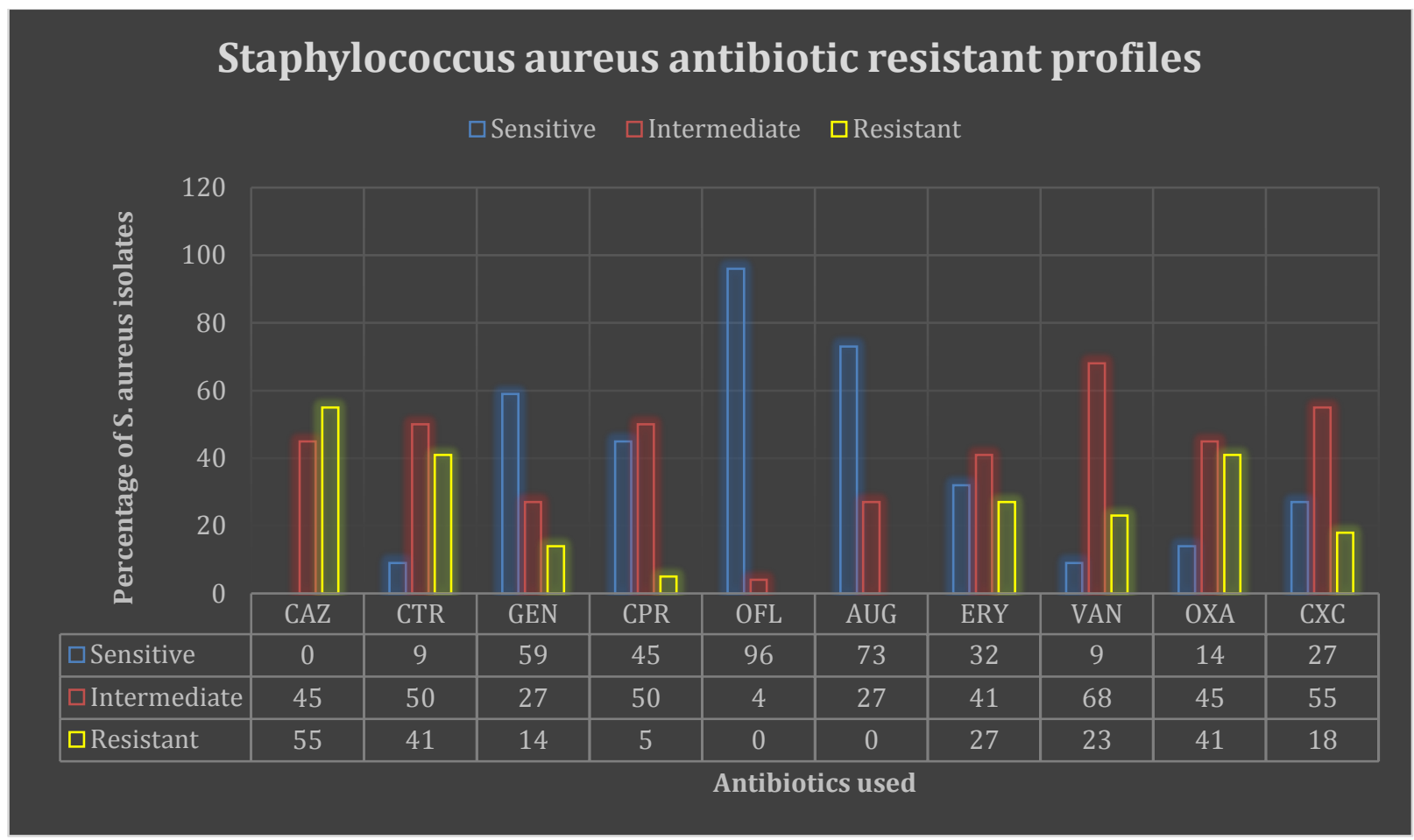

Figure 4 -Antibiotics resistant profiles of the Staphylococcus aureus isolates

Table 2 - Multidrug resistance in the Staphylococcus aureus isolates

\begin{tabular}{|c|c|c|c|c|c|c|}
\hline \multirow[t]{2}{*}{ S. aureus isolates } & \multicolumn{5}{|c|}{ Antimicrobial category } & \multirow{2}{*}{\begin{tabular}{|l|} 
MDR \\
status
\end{tabular}} \\
\hline & $\begin{array}{c}\text { Aminoglycosides } \\
\text { (GEN) }\end{array}$ & $\begin{array}{c}\text { Fluoroquinolones } \\
\text { (CPR) }\end{array}$ & $\begin{array}{c}\text { Macrolides } \\
\text { (ERY) }\end{array}$ & $\begin{array}{l}\text { Glycopeptides } \\
\text { (VAN) }\end{array}$ & $\begin{array}{l}\text { Anti-Staphylococcal Beta } \\
\text { Lactams (OXA) }\end{array}$ & \\
\hline KZ1 & $S$ & NS & $S$ & NS & NS & MDR \\
\hline KZ2 & $S$ & NS & $S$ & NS & NS & MDR \\
\hline KZ3 & NS & $S$ & S & NS & NS & MDR \\
\hline KZ4 & NS & $\mathrm{S}$ & NS & $\mathrm{S}$ & NS & MDR \\
\hline KZ7 & $S$ & S & NS & NS & NS & MDR \\
\hline KZ10 & S & S & NS & NS & $S$ & $\begin{array}{l}\text { NO } \\
\text { MDR }\end{array}$ \\
\hline KZ11 & S & NS & S & NS & NS & MDR \\
\hline KZ12 & $\mathrm{S}$ & $\mathrm{S}$ & NS & NS & NS & MDR \\
\hline KZ13 & S & S & S & NS & S & $\begin{array}{l}\text { NO } \\
\text { MDR }\end{array}$ \\
\hline KZ14 & S & NS & NS & NS & NS & MDR \\
\hline KZ19 & NS & NS & NS & NS & $\mathrm{S}$ & MDR \\
\hline KZ21 & S & S & NS & NS & NS & MDR \\
\hline KZ22 & NS & S & NS & NS & NS & MDR \\
\hline KZ25 & NS & NS & NS & NS & NS & MDR \\
\hline KZ28 & NS & NS & NS & NS & NS & MDR \\
\hline KZ29 & NS & NS & NS & NS & NS & MDR \\
\hline KZ30 & NS & S & $S$ & NS & NS & MDR \\
\hline KZ31 & $S$ & NS & NS & $S$ & NS & MDR \\
\hline KZ34 & S & NS & NS & NS & NS & MDR \\
\hline KZ35 & S & NS & $S$ & NS & NS & MDR \\
\hline KZ36 & NS & $S$ & NS & NS & NS & MDR \\
\hline KZ40 & S & NS & NS & NS & NS & MDR \\
\hline $\begin{array}{l}\text { MDR Incidence } \\
\text { Percentage }\end{array}$ & & & & & & $91 \%$ \\
\hline
\end{tabular}

Notes: $\mathrm{S}=$ susceptible, NS=non-susceptible 
With regards to antibiotic resistance, MRSA, VRSA and ESBL producing Enterobacteriaceae are currently of particular public health concern. In this study, $41 \%$ of the isolates were MRSA, $23 \%$ were
VRSA and $68 \%$ were VISA (Figure 4 ). In addition, $26 \%$ of the Salmonella spp isolates were confirmed to be ESBL producers based on the DDST (Figure 5).

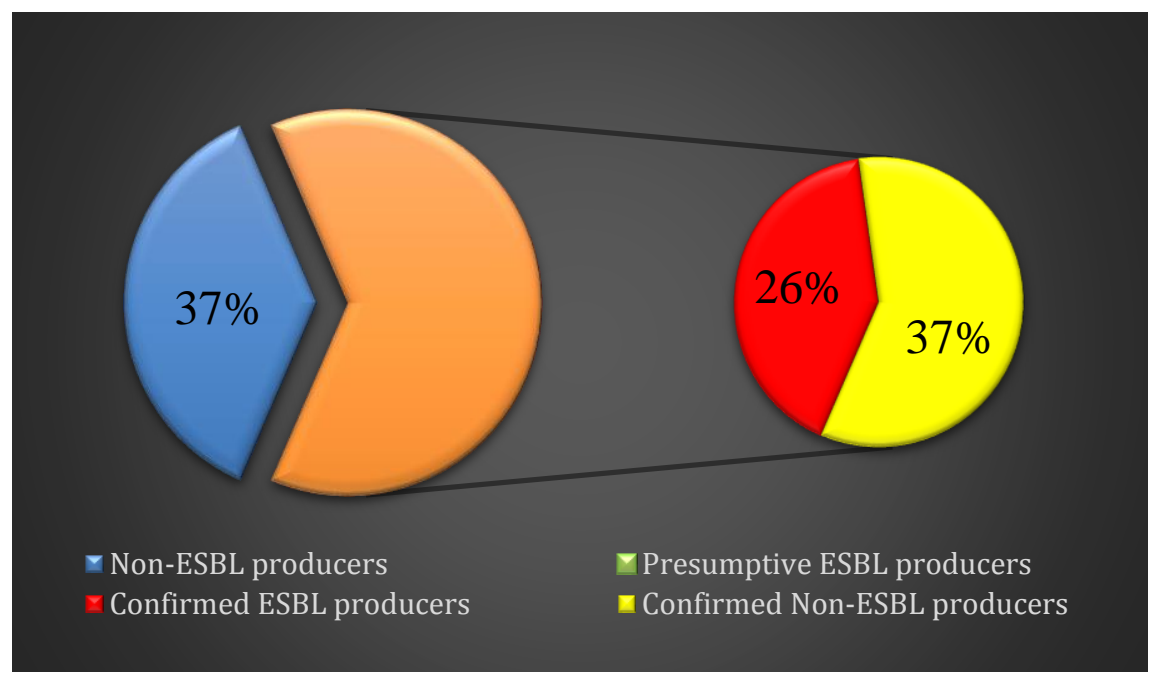

Figure 5 - Percentage occurrence of ESBL producing Salmonella spp based on the phenotypic breakpoint and Double Disc Synergy Test (DDST)

Previously, vancomycin has been widely utilized for the treatment of MRSA infections and this has led to the emergence of VRSA and VISA [25]. Following treatment of MRSA patients with vancomycin, VISA isolates emerged as a result of mutations in MRSA isolates [50].

\section{CONCLUSION}

The results obtained from this study revealed that Kunun-zaki sold in Umuahia metropolis, Nigeria, is contaminated with important bacterial foodborne pathogens, and whose counts do not conform to the standard limits of detectable microbes in ready-to-eat foods as stipulated by the Center for Food Safety. Hence, the consumption of these products may constitute serious public health concerns if not correctly quality controlled. From this study, it is evident that this product could include a source of ESBL producing Salmonella, MRSA and VRSA, amongst other pathogenic microbes which were not detected in the study but have been previously reported. Whilst consumption of Kunun-zaki is encouraged due to its health and nutritional benefits as registered from recent and previous studies, its production, processing and packaging should be regulated appropriately, and strict compliance with acceptable hygiene practices during any step of preparation, storage and distribution to the final consumer are essential to prevent contamination with foodborne pathogens and any health complications that may result thereof.

\section{REFERENCES}

1. Maji, A. A., James, O., \& Chigozie, O. E. (2011). Effects of chemical treatment and pasteurization on the shelf life of Kunun-zaki (sorghum and maize gruel). European Journal of Nutrition and Food Safety, 1(2), 61-70.

2. Efiuvwevwere, B., \& Akona, O. (1995). The microbiology of 'Kunun-zaki', a cereal beverage from Northern Nigeria, during the fermentation (production) process. World Journal of Microbiology and Biotechnology, 11(5), 491-493.

3. Akoma, O., Jiya, E., Akumka, D., \& Mshelia, E. (2006). Influence of malting on the nutritional characteristics of Kunun-zaki. African Journal of Biotechnology, 5(10), 996-1000. 
4. Terna, G. \& Ayo, J. (2002). Innovations in the traditional Kunun-zaki production process. Pakistan Journal of Nutrition, 1(5), 202-205. doi:10.3923/pjn.2002.202.205

5. Uvere, P. O., \& Amazikwu, U. C. (2011). Processing and evaluation of instant Kunun-zaki from milletcowpea and millet-soybean malt. African Journal of Food Science, 5(14), 761-768. doi: 10.5897/AJFS11.069

6. Adebayo, G., Otunola, G., \& Ajao, T. (2010). Physicochemical, microbiological and sensory characteristics of Kunu prepared from millet, maize and guinea corn and stored at selected temperatures. Advance Journal of Food Science and Technology, 2(1), 41-46.

7. Ikpoh, I., Lennox, J., Agbo, B., Henshaw, E., \& Udoekong, N. (2013). Microbial quality assessment of Kunun beverage locally prepared and hawked in Calabar, Cross River State, Nigeria. Global Journal of Biodiversity Science and Management, 3(1), 58-61.

8. Elmahmood, A., \& Doughari, J. (2007). Microbial quality assessment of Kunun-zaki beverage sold in Girei town of Adamawa State, Nigeria. African Journal of Food Science, 1(1), 11-15.

9. Amusa N., \& Odunbaku, O. (2009). Microbiological and nutritional quality of hawked Kunun (a sorghum based non-alcoholic beverage) widely consumed in Nigeria. Pakistan Journal of Nutrition, 8(1), 20-25. doi: 10.3923/pjn.2009.20.25

10. Makut, M. D., Nyam, M. A., Obiekezie, S. O., \& Abubakar, A. E. (2013). Antibiogram of bacteria isolated from Kunun-zaki drink sold in Keffi Metropolis. American Journal of Infectious diseases, 9(3), 71-76. doi: 10.3844/ajidsp.2013.71.76

11. Osuntogun, B., \& Aboaba, O. (2004). Microbiological and physico-chemical evaluation of some nonalcoholic beverages. Pakistan Journal of Nutrition, 3(3), 188-192.

12. Olasupo, N., osikoya, A., Kuboye, A., Olatunii, O., \& Odunfa, S. (2000). An investigation on the preservation of Kunun-zaki, an African fermented cereal based food drink. Acta Alimentaria, 29(4), 385-392. doi: 10.1556/aalim.29.2000.4.9

13. Ofudje, E., Okon, U., Oduleye, O., \& Williams O. (2016). Proximate, mineral contents and microbial analysis of Kunun-zaki (a non-alcoholic local beverage) in Ogun State, Nigeria. Journal of Advance in Biology and Biotechnology, 7(1), 1-8. doi: 10.9734/JABB/2016/26670

14. Nyanzi, R., \& Jootse, P. (2012). Cereal based functional foods. In E. Rigobelo (Ed.), Probiotics (pp. 161-197). IntechOpen. doi: 10.5772/50120

15. Edward, K. C., Alozie, C. E., Owuamalam, P. O., \& Onyekachi, O. V. (2019). Screening of Kunun-zaki for the presence of extended spectrum beta lactamase and carbapenemase producing Escherichia coli. SAR Journal, 2(4), 158-166. doi: 10.18421/SAR24-03

16. Yusha'u, M., Abubakar, H. M., \& Kawo, A. H. (2010). Commercial foods as potential sources of extended spectrum $\beta$-lactamses (ESBL) producers in Kano, Nigeria. International Journal of Pharmaceutical Applied Sciences, 1(1), 59-62.

17. Todar, K. (2009). Todar's Online Textbook of Bacteriology 2008. Retrieved from http://www.textbookofbacteriology.net/kt_toc.html

18. Winn, W., Allen, S., Janda, W., Koneman, E., Procop, G., Schreckenberger, P., \& Woods. G. (2006). Koneman's Color Atlas and Textbook of Diagnostic Microbiology (6th ed.). Philadelphia: Lippincott Willams and Wilkins.

19. Hall, G. S. (2003). MRSA: Lab detection, epidemiology, and infection control. Microbiology Frontlines, 3, 1-6.

20. Arunkumar, V., Prabagaravarthanan, R., \& Bhaskar, M. (2017). Prevalence of Methicillin-resistant Staphylococcus aureus (MRSA) infections among patients admitted in critical care units in a tertiary care hospital. International Journal of Research in Medical Sciences, 5(6), 2362-2366. doi: 10.18203/2320-6012.ijrms20172085 
21. Otto, M. (2017). Next generation sequencing to monitor the spread of antimicrobial resistance. Genome Medicine, 9(1), 1-3. doi: 10.1186/s13073-017-0461-x

22. Rodriguez-Noriega, E., Seas, C., Guzman-Blanco, M., Mejia, C., Alvarez, C., Bavestrello, L., Zurita, J., Labarca, J., Luna, C. M., Salles, M. J., \& Gotuzzo, E. (2010). Evolution of methicillin resistant Staphylococcus aureus clones in Latin America. International Journal of Infectious Diseases, 14(7), 560-566. doi: 10.1016/j.ijid.2009.08.018

23. Milheirico, C., Oliveira, D. C., \& de Lencastre, H. (2007). Update to the multiplex PCR strategy for assignment of mec element types in Staphylococcus aureus. Antimicrobial Agents and Chemotherapy, 51(9), 3374-3377. doi: 10.1128/AAC.00275-07

24. Okwu, M. U., Mitsan, O., Oladeinde, B., Palmans, I., \& Van Dijck, P. (2016). Staphylococcal cassette chromosome mec (SCCmec) typing of methicillin resistant Staphylococci obtained from clinical samples in South-South, Nigeria. World Journal of Pharmacy and Pharmaceutical Sciences, 5(7), 91-103. doi: 10.20959/wjpps20167-7110

25. Dhanalakshmi, T., Umapathy, B., \& Mohan, D. (2012). Prevalence of methicillin, vancomycin and multi drug resistance among Staphylococcus aureus. Journal of Clinical and Diagnostic Research, 6(6), 974-977.

26. Blair, J. M., Webber, M. A., Baylay, A. J., Ogbolu, D. O., \& Piddock, L. J. (2015). Molecular mechanism of antibiotic resistance. Nature Reviews Microbiology, 13(1), 42-51. doi: 10.1038/nrmicro3380

27. Bush, K. (2013). The ABCD's of beta lactamase nomenclature. Journal of Infection and Chemotherapy, 19(4), 549-559. doi: 10.1007/s10156-013-0640-7

28. Deschamps, C., Clermont, O., Hipeaux, M. C., Arlet, G., Denamur, E., \& Branger, C. (2009). Multiple acquisition of CTX-M plasmids in the rare D2 genotype of Escherichia coli provide evidence for convergent evolution. Microbiology, 155(5), 1656-1668. doi: 10.1099/mic.0.023234-0

29. Altayb, H. N., El Amin, N. M., Mukhtar, M. M., Salih, M. A., \& Siddig, M. A. (2014). Molecular characterization and in silico analysis of a novel mutation in TEM-1 beta lactamase gene among pathogenic E. coli infecting a Sudanese patient. American Journal of Microbiological Research, 2(6), 217-223. doi: 10.12691/ajmr-2-6-8

30. Knothe, H., Shah, P., Krcmery, V., Antal, M., \& Mitsuhashi, S. (1983). Transferable resistance to cefotaxime, cefoxitin, cefamandole and cefuroxime in clinical isolates of Klebsiella pneumoniae and Serratia marcescens. Infection, 11(6), 315-317. doi: 10.1007/BF01641355

31. Edward, K. C., Owuamalam, P. O., Onyekachi, O. V., Nnochiri, O. A., \& Akumah, C. N. (2017). Microbial quality assessment of ice cream sold in Umuahia, South-Eastern, Nigeria: A comparative study. Journal of Biology, Agriculture and Healthcare, 7(16), 40-48.

32. Shu'aibu, I., Hadiza, J., Yusha'u, M., Kabiru, M., Lawal, G., Adamu, M. T., \& Khairiyya, M. (2018). Assessment of foods and drinks for the presence of extended spectrum beta lactamase (ESBL) producing bacteria in Gombe Metropolis, Nigeria. Advanced Science Letters, 24(5), 3646-3651. doi: 10.1166/asl.2018.11457

33. Opeyemi, A. F., \& Obuneme, O. S. (2020). Bacteriological and nutritional assessment of tiger nut milk (Kunun-aya) consumed by students of Nasarawa State University, Keffi, Nigeria. World Journal of Advanced Research and Reviews, 6(3), 059-068. doi: 10.30574/wjarr.2020.6.3.0097

34. Ntukidem, V. E., Edima-Nyah, A. P., Ndah, L. S., \& Abraham, N. A. (2002). Assessment of Microbiological Safety and Organoleptic properties of tiger nut (Cyperus esculentus) beverage processed locally and sold in Uyo Metropolis of Akwa Ibom State, Nigeria. International Journal of Food Nutrition and Safety, 11(1), 37-50.

35. Cheesbrough, M. (2006). District laboratory practice in tropical countries (2nd ed.). Cambridge: Cambridge University Press. 
36. Clinical and laboratory standard institute. (2020). Performance standards for antimicrobial susceptibility testing (M100). Reteieved from https://clsi.org/media/3481/m100ed30_sample.pdf

37. Clinical and laboratory standard institute. (2014). Performance standards for antimicrobial susceptibility testing (M100-S24). Retrieved from https://www.researchgate.net/file.PostFileLoader.html?id=59202a0696b7e4d462166956\&ass etKey $=\mathrm{AS} \% 3 \mathrm{~A} 496054988533760 \% 401495280134033$

38. Jarlier, V., Nicolas, M. H., Fournier, G., \& Philippon, A. (1988). Extended broad-spectrum beta lactamases conferring transferable resistance to newer beta lactam agents in Enterobacteriaceae: hospital prevalence and susceptibility patterns. Reviews of Infectious Diseases, 10(4), 867-878. doi: 10.1093/clinids/10.4.867

39. Bradford, P. A. (2001). Extended spectrum beta lactamases in the 21st century: characterization, epidemiology, and detection of this important resistance threat. Clinical Microbiology Reviews, 14(4), 933-951. doi: 10.1128/cmr.14.4.933-951.2001

40. Chaudhary, U., \& Aggarwal, R. (2004). Extended spectrum beta lactamases (ESBL)- an emerging threat to clinical therapeutics. Indian Journal of Medical Microbiology, 22(2), 75-80.

41. Gyar, S., Bala, H., \& Reuben, C. (2014). Bacteriological quality assessment of Nigerian Non-alcoholic beverage (Kunun-zaki) sold in Keffi Metropolis, Nigeria. Greener Journal of Microbiology and Antimicrobials, 2(2), 21-25. doi: 10.15580/GJMA.2014.2.0513014231

42. Braide, W., Adeleye, S., Ukagwu, N., \& Lugbe, P. (2018). Chemical properties and microbiological profile of Kunun zaki, a non-alcoholic beverage. Biomedical Journal of Scientific and Technical Research, 4(1), 3731-3735. doi: 10.26717/BJSTR.2018.04.001001

43. Aboh, M., \& Oladosu, P. (2014). Microbiological assessment of Kunun-zaki marketed in Abuja Municipal Area Council (AMAC) in the Federal Capital Territory (FCT), Nigeria. African Journal of Microbiology Research, 8(15), 1633-1637. doi: 10.5897/AJMR2013.5779

44. Center for food safety. (2014). Microbiological guidelines for food. Retrieved from https://www.cfs.gov.hk/english/food_leg/files/food_leg_Microbiological_Guidelines_for_Food_e. pdf

45. European Food Safety Authority \& European Center for disease prevention and control (ECDC) (2015). The European Union summary report on trends and sources of zoonoses, zoonotic agents and foodborne outbreaks in 2014. EFSA Journal, 13(12), 4329. doi: 10.2903/j.efsa.2015.4329

46. Essien, E., Monago, C., \& Edor, E. (2011). Evaluation of the nutritional and microbiological quality of Kunun (a cereal based non-alcoholic beverage) in Rivers State, Nigeria. Internet Journal of Nutrition and Wellness, 10(2).

47. Magiorakos, A. P., Srinivasan, A., Carey, R. B., Carmeli, Y., Falagas, M. E., Giske, C. G. Harbarth, S., Hindler, J. F., Kahlmeter, G., Olsson-Liljequist, B., Paterson, D. L., Rice, L. B., Stelling, J., Struelens, M. J., Vatopoulos, A., Weber, J. T., \& Monnet, D. L. (2012). Multidrug-resistant, extensively drug resistant and pandrug resistant bacteria: an international expert proposal for interim standard definitions for acquired resistance. Clinical Microbiology and Infection, 18(3), 268-281. doi: 10.1111/j.1469-0691.2011.03570.x

48. Angulo, F., Nargund, V. N., \& Chiller, T. M. (2004). Evidence of an association between use of antimicrobial agents in food animals and antimicrobial resistance among bacteria isolated from humans and the human health consequences of such resistance. Journal of Veterinary Medicine Series, 51(8-9), 374-379. doi: 10.1111/j.1439-0450.2004.00789.x

49. Edward, K. C., Onyekachi, O. V., Owuamalam, P. O., Nnochiri, O. A., \& Alozie, C. E. (2018). Prevalence and antibiogram of coagulase positive Staphylococci isolated from farm animals in Michael Okpara University of Agriculture, Umudike, South-Eastern Nigeria. IOSR Journal of Pharmacy, 8(12), 20-26. 
50. Gardete, S., \& Tomasz, A. (2014). Mechanism of vancomycin resistance in Staphylococcus aureus. Journal of Clinical Investigation, 124(7), 2836-2840. doi: 10.1172/JCI68834 